\title{
The Study of Power System Reform with the Goal of Sustainable Development
}

\author{
Qu TianYi \\ School of Management \\ XuZhou institute of Technology \\ Xuzhou, Jiangsu, 221008, China \\ e-mail: jdbh2001@163.com
}

\begin{abstract}
This paper expounds the course and accomplishment of the power system reform at home. Then, according to the power system reform experience of other countries, the paper analyses the existing problems of regulatory mechanism and pricing system which occurs in the process of domestic power system reform. Finally, combined with the power industry and other community realities in china, the paper put forward some suggestions about the future power system reform.In the course of the power system reform, the goal that building a electric power industry system which is safe, reliable, green low-carbon, energy conservation, integrated resource optimization, sustainable and healthy development, is the premise of ensuring the smooth progress of reform. Meanwhile, establishing a strong and unified leadership organization, impartial and effective regulatory regime, sound and reasonable price formation mechanism, sound market environment and introducing competition mechanism are the ensurance of the smooth conduct of the electricity reform.
\end{abstract}

Keywords-power system; reform; regulatory; electricity price; monopoly

\section{INTRODUCTION}

China's market reform of power system acquired significant progress in 2002, with the structure innovation of theseparation between power plant and power grid as the core, the electricalgenerationwill separatewith the naturalmonopoly power grid , besides, independent power regulator had been founded.Although electricity reform program in "Notice of the State Council on issuing power system reform" had been widely recognized since 2002, there was no satisfactory progress afterwards.Recent years, theoretical circle and policy community constantly reflected and summarized the problems of the route of power system reform in china,however,not only clear blueprint and real and feasible implementation measures hadn't been formed,but also deep problems of power system hadn't been involved.If these problems can't be solved effectively, the power system reform scarcely achieved satisfactory results. Therefore,new research boom of power system reform has been further opened since Eighteen of the Third Plenary Session.

This paper begins with the history of china's power system reform,after combining with china's actual conditions and characteristics, learning from the power system reform of other countries, analyzing the major problems of domestic power system reform, puts forward some suggestions about the future power system reform.And hope that it will be helpful to domestic power system reform.

\section{THE PROCESS AND ACCOMPLISHMENTS OF DOMESTIC POWER SYSTEM REFORM}

China's power system reform began at 1980s .This period can be separatedinto several stages according to the process and content of the reform .First stage : 1978 1997 , from 1978 to 1985,the government implemented the policy that bank loans can be used to the concept that 'raising money for electricity', which changed the phenomenon that powerconstruction only relied on financial allocations. The way according to the principles of servicing the debt verifying the electricity price level break the single mode of electricity price ,cultivating the mechanism which set the electricity according to the market rule.From 1978 to 1997,power industry carried out the policy'separating government functions from enterprise management ', which meant that abolishing ministry of power industry and founding State Power Corporation which would undertake five regional corporation group,seven Provincial Power Company and 2 immediate groups--Huaneng along with Gezhouba .The reform in this period not only broke the situation that State run electricity, mobilizing the enthusiasm of all aspects, but also enlarging the capacity of power system, however,the problems such as technically outdated projects ,the slowing development of power transmission and distribution,chaos increases and arbitrarycharges had emerged.

The second stage ,1998 2000; after abolishing ministry of power industry in 1998, the administrative authority of power industry was handed over to The State EconomicCommission and the local government.During this period ,thegovernmentmainly engaged withthe reform onsuch aspects such as shutting down small coal enterprises, reconstruction of city power grid,accelerating the construction of wind power and hydropower, cancelling chaos increases and arbitrarycharges, as well as verifying average feed-in tariffs according to the operating period of the project.Until the end of 2000, most of the provinces realized the goal that separating government 
functions from enterprise management,but problems still existed in monopoly, competition and regulatory and so on.

The third stage, 2001 2014.11; the State Council carried out the policy that" Notice of the State Council on issuing power system reform", in which it decided to start a new round of power system reform that majored in'separating powerplantsfromthepowergrids, bidding, breaking monopoly, introducing competition'. The former StatePower Corporation was separated into the two power grid companies,five power generation groups, four auxiliary power Industry group.

\section{THE MODE OF POWER SYSTEM REFORM ABROAD}

The earliest power system reformstarted in Britain and America.Considering the mode of reform ,on account of different realities in varied countries and differentmode of reform,so there was no widely used mode .But the former experiences can still provide china's power system reform with some experiences and reflections.

Britain's electricity reform began in the early nineties, the original generation, transmission, and distribution in one of the Central Electricity is divided into three parts.The power generation part established independently operated NationalPower International Corporation, National power company, State Nuclear Power Company and some independent private power producers which would complete in the market. The transmission section set up a powerbase which was In charge of the transmission grid and dispatch center ,the base not only was responsible for maintaining stable and economic operation of the grid as well as the development of power grid ,but also promote the competition between power generation sector andpower link.The distribution section established twelve regional power distribution companies and some independent private power companies, whichwas directly engaged in thebusiness of selling electricity. The core of the UK's electricity reform was establishing the trading mechanismthat more purchasing(power generation) and more selling (sale of electricity), firmly grasping the competition between power generation sector andsale of electricity link; transmission and distribution sectorswere regarded as a natural monopoly .The separation between transmission , distribution sectors and power generation sector, sale of electricity link was to meter the costs of the transmission and distribution .easily. The most important factor of success of the UK's electricity reform was Introducing and constantly improving the mechanism of competition ,and power tended to be more market-oriented pricing.

American's electric power system reform began at the late eighties of the last century, the main contents of the reform were releasing power generation sector ,implementing diversified investment, allowinginvestorswhich weren't the public power corporations to build factories, which made the independent power plants which weren't owned by power company develop quickly. The public power corporations changed their former vertical management model ,reconstructed a group of holdingsubsidiary companies ,implemented separatingmanagement of transmission subsystemas well as separating settlement of transmission and distribution. The policy encouraged competition among different power plants and competition between independent power plants with market price and power plants of power company. American's electric power system reform relied onstandardized operation of the market,sound legal systemas well as modern electricity production, an orderly competition based on scheduling and sales, the core of the reform was breaking monopoly ,deregulating to encourage competition in the generation and sale of electricity link and strengthening supervision in transmission and distribution sectors.

Russia's power system reform began at 1992 .The reform successively went through three stages, Russia split the Unified Energy Systems Corporation, grid assets concentrated in the hands of the Federal Grid Company and other large groups, which also meant that Russia completed the spin-off of the power industry completely ,various aspects ofgeneration, transmission, distribution, sale, scheduling and transaction were fully independent .However, a series of problems such as continued soaring electricity price, re monopoly power ,low efficiency in power grid link and facing difficulties in Investment . In 2012, faced with a series of social problems caused by soaring electricity prices ,the Russian government will merge with power transmission gridand distribution network companies in the direction of renationalization .In 2013, merger and reorganization plans officially entered the operational phase, which meant that the Russianpower system reform came back to the origin .

As shown in Table 1 were the mode of power system reform abroad .

TABLE I. THE MODE OF POWER SYSTEM REFORM ABROAD

\begin{tabular}{|c|c|}
\hline Country & The Mode of Power System Reform \\
\hline Britain & $\begin{array}{l}\text { monopoly of transmission links, competition ofgeneration, } \\
\text { distribution and sale of electricity links, establishing an } \\
\text { open electricity market }\end{array}$ \\
\hline Germany & $\begin{array}{l}\text { monopoly of transmission and distribution links, free } \\
\text { competition of generation and sale of electricity }\end{array}$ \\
\hline France & $\begin{array}{l}\text { Keep verticalintegration andnationalizedmonopolyin } \\
\text { electricitygeneration,transportation,distribution and selling }\end{array}$ \\
\hline $\begin{array}{l}\text { US PJM } \\
\text { mode }\end{array}$ & $\begin{array}{l}\text { monopoly of transmission links, competition of generation, } \\
\text { distribution and sale of electricity links, establishing an } \\
\text { open electricity market }\end{array}$ \\
\hline $\begin{array}{l}\text { Californi } \\
\text { a Mode } \\
\text { of USA }\end{array}$ & $\begin{array}{l}\text { completely separation among power generation, } \\
\text { transmission and distribution and the introduction of } \\
\text { competition ; Supply companies buy electricity directly } \\
\text { from the power generation company , transmission } \\
\text { company only play the role of the transmission }\end{array}$ \\
\hline Japan & Regional vertically integrated monopoly \\
\hline Russia & $\begin{array}{l}\text { various aspects of generation, transmission, distribution, } \\
\text { sale, scheduling } \quad \text { and } \\
\text { completelycompeted, vertically integrated operations in } \\
2012\end{array}$ \\
\hline
\end{tabular}

In terms ofthe reform of power system abroad, the reform abroad organized power system reform relying mainly ongovernment . It mainly reformed in such aspects , such as power control mode, price formation mechanism and the introduction of market competition mechanism .The countries which had a high degree of market, clear goal of reform and sound legal mechanism finally reached a better results of reform . 


\section{THE MAIN PROBLEMS OF CURRENT POWER SYSTEM REFORM}

Combining the problems and controversy in the process of reformand the power system reform experience of other nations, there are the following problems:

(1) The regulatory system

At present, the administrative department of the electric power industry in our country is not regulated, and there are multiple departments condominium. There are many departments: The National Development and Reform Commission which is responsible for the determination of electricity price,Electricity Regulatory Commission under the National Energy Board which is responsible for electricity regulation,SASAC which is responsible for the performance evaluation of power company officials, the National Development and Reform Commission which is responsible for the power project approval.The above departments sometimes interact with each other,influencing the power regulation efficiency. price

(2)The mechanismproblem of determine the electricity

At present, our country's electricity price is determined by the direct approval method that use the way of cost-plus pricing,hindering the cultivation of competitive market and intensifying the game and rent-seeking space.The method of determining the electricity power lacks the clear rules, transparency and openness. Whether a feed-in tariff or sell electricity prices all exist the problems that theyare supervised severely,which does not benefit the cultivation of competitive market.

(3)The natural monopoly of power transmission

Besides the natural monopoly in our country,there are also scheduling monopoly, trade monopoly and purchaseand-sell monopoly. The combination of the purchase and sale price difference profit model and scheduling monopoly and the ownership of power quantity planning improve the profitability of the power grid,but seriously damage the profits of fair competition and power suppliers.And the monopoly of the transmission and distribution business, scheduling, selling electricity business aggravates the game power of the grid under the condition of asymmetric information, and reduces the government regulation ability. That is not propitious to the sustainable development of the electric power industry in the future.

\section{(4)Information asymmetry}

Determining a reasonable electricity price need effectively master all aspects of the accurate information.Each side only has a clear grasp of their own information in the electric power industry.For the other person's information, due to the limited access, there is no accurate comprehensive information.All information are often inconsistent, making the final price is decided by the superior departments, rather than a science, market price.

(5)The reform of thinking and practice

The reform of electric power lacks the top design and the overall progress,dares not touch the vested interests, just limited to partial or incremental improvements. Aiming at the national electric power system reform for more than a decade, there has been two different opinions about the file No.5,pros and cons, its essence is the market and non-market debate.At present, the vested interest group which support opposing the file No. 5 has the upper
hand.Since the file No.5 appeared,from the perspective of the electric reform, its system design has no large deviation, but can not be effective executed.

\section{SOME SUGGESTIONS ABOUT POWER SYSTEM REFORM OF CHINA}

The former power system reform which began at 2002 , on account of a variety of reasons, didn't reached the original goal. The new reform which was leading by the National Development and Reform Commission at the end of 2014 ,put forward 'four liberalizations , an independent policy, a strengthening policy', which meant the opening of operating price outside transmission and distribution ,the opening of new distribution business ,the opening of sale of electricity, the opening of generation plan ,relative independent of trading platform and strengthening the planning . Among them, the opening of generation plan, electricity price, distribution ,sale of electricity and so on was hopefully realized. The opening of generation plan, which means the government will no longer formulating power plan. The opening of electricity price, which means thepower plant andthe user can directlyset the price oftransactions except that transmission and distribution tariffs approved by the State. Power distribution side releasing ,allowing social capital investment in new distribution network. Establishing the sale of electricity company, allowing private capital to enter the field of distribution and sale of electricity .Trading institutionsstay alone and thepower gridplanning is strengthening, the price of electricity transmission and distribution only approved by the state . While the above reform program is basically recognized, in order to ensure the smooth implementation of the program .

I believe that the following issues need to be addressed .Thus, preventing the situation that only program introduced, reform can't be carried on .

(1)the purpose of the power system need to be unified

Recently, experts and scholars have done a lot of research on China's power system reform ,but on account of different goal of the reform, it will inevitably lead to the differences of reform program and the method .For example ,the problem that whether to split the grid ,there exists two different issues. To solve this kind of dispute ,the first step is clarifying the purpose of splitting the grid, discussions only under this unified premise can be more meaningful .I believe that ,the purpose of China's electric power system reform is establishing a secure, reliable, green low-carbon, energy conservation, integrated resource optimization, sustainable and healthily developing electric power industry system ,pushing the overall transformation of electricity energy production, consumption and the technical structure which is complying with China's general energy trend , promoting the coordinated development of economy and society, protectingthe strategy of national energy security .Only under the clarified premisecan we compare and analyze the various options, then select the best reform program .

(2)establishing strong government power reform organizations

Currently, China's power industry has no unified management ,existing the problem of condominium of 
multiple departments. And in the reform process the interests of certain sectors is bound to be broke ,the reform process is the process that all aspects and various departmentplay the game .Therefore, in order to ensure the smooth progress of the power system reform,

a strong unified government power reform organizations must be established at the national level . which is responsible for the overall reform of electric power system .Meanwhile, this agency guides the the overall reform work on the basis of the goal of power system reform, overall plans, develops the framework of reform ,implementation methods, problems that may be encountered and the solutions to the problems .

(3)establishing the regulation of promoting the sustainable development of power industry

As for the power industry which has natural monopoly characteristic ,to establish an effective supervision systemis the important condition and system security which ensure fair competition and protect the sustainable and healthy development of electric power. In the aspect of supervision, it should be based on the construction of legal system . Establishing standardized and institutionalized regulatory mechanisms is helpful to overcome the failures and deficiencies of government regulation, reduce and avoid the happening of the phenomenasuch as regulators being captured by corporate interests, corporate rentseeking, information asymmetries. Moderate relaxation in entry regulation and price regulation ,implementing incentive regulation and consultative regulation, while strengthening the electricity regulatory . Establishing effective competitionis the concept of policy trend of government regulatory. Only following the market systemand Introducing healthy competition can promote the sustainable development of the power sector

(4)establishing a rational price formation mechanism

Tariff reform is an important part of the power systemreform, which is meaningful to establish and nurture the electricity market, optimize power allocation of resources and promote healthy and sustainable development of the power industry . Price is divided into tariff, transmission prices, distribution and terminal sales price of electricity; the price of power generation and electricity salesis formed by market competition ; Establishing a standardized and transparent pricing management system,only government can decide the reasonable price of transmission and distribution .Meanwhile, priceshould be able to guidethe power industryinthe long-term, healthy development ,and play a guiding rule to other industry .

(5)introducing market competition mechanism , cultivating good competitive market

Introducing market competition mechanism and establishing a fair, just, open and competitive market environment are the only way of building a electric power industry system which is safe, reliable, green low-carbon, energy conservation, integrated resource optimization, sustainable and healthy development .Recently, China's power system reform still exists mechanism gaps of bilateral auction ; the power grid's purchasing scale or the electricity output scale essentially co-led by the government and the power grid; the rules of short-term electricity market, power assisted market and futures market are blank ;although there exists a very small portion of the competition of replacing battery, there are some problems in fair, open and transparent terms ; There exists monopoly in electricity transmission and distribution .Evidently ,there basically doesn't have market competition .Therefore, market competition mechanism need to be vigorously introduced, only in this way, can we effectively promote the sustainable development of the power industry .

\section{CONCLUSIONS}

In the course of the power system reform, the goal that building a electric power industry system which is safe, reliable, green low-carbon, energy conservation, integrated resource optimization, sustainable and healthy development, is the premise of ensuring the smooth progress of reform . Meanwhile, establishing a strong and unified leadership organization, impartial and effective regulatory regime, sound and reasonable price formation mechanism,sound market environment and introducing competition mechanismare the ensurance of the smooth conduct of the electricity reform .

\section{REFERENCES}

[1] Yongsheng Feng, Allocative Efficiency of the Vertical Structure and Power System Reform in China[J], Finance and Trade Economics , 2014(7)128-136.

[2] Zhimin Li, A Comparative Study of English and Chinese Electric Power System Reform[D] , Anhui University ,2013.

[3] Guoren Li, The Enlightment of the Mode of Developed Countries' Power System Reform in China [J] , Decision Consulting , 2012(05) 8-14.

[4] State Electricity Regulatory Commission, The Market of American Power System[M],Beijing: China Electric Power Press , 2005.

[5] Mei Bai, Target of Difficulties and Path Selection of the New Round of Power System Reform[J] , Price Theory and Practice 2014(07)10-15

[6] ZeYe, Consensus of Power System Reform [J] ,China Power Enterprise Management , 2014(12)56-61.

[7] Chengzhang Zhu, Narrowing the Difference of the Power System [J], China Power Enterprise Management , 2014(8)14-19.

[8] Dan Shi, Target Selection of Chinese Power System Reform [J], China Energy , 2014(8)6-9.

[9] Peng J C, Jiang H. Fair and analytical allocation of transmission losses using a two-step coalitional game. IEEE PES General Meeting, 6-10 June, 2004, $6: 186-191$

[10] Oliveira E J, Silva I C, Pereira J L R, et al. Transmission system expansion planning using a sigmoid function to handle integer investment variables. IEEE Transactions on Power Systems, 2005, 20(3) : 1616-1621Dan Shi, Target Selection of Chinese Power System Reform [J], China Energy , 2014(8)6-9. 